\title{
Penerapan Rules and Procedures Untuk Meningkatkan Kedisiplinan Siswa
}

\author{
Lina Lumbantoruan, Widiastuti, Wiyun Philipus Tangkin
}

Program Studi Pendidikan Guru Sekolah Dasar, Fakultas Ilmu Pendidikan

Universitas Pelita Harapan, Indonesia

*widiastuti.tc@uph.edu

\begin{abstract}
Discipline is very necessary in the learning process, but in fact there are still many students who show an undisciplined attitude. Based on the results of observations in several classes at one of the Christian Junior High Schools in Medan, it was found that there were still more students who did not collect their assignments than those who did. Therefore, it is necessary to implement rules and procedures. The purpose of this paper is to describe the application of rules and procedures to improve student discipline. The research method used is descriptive qualitative. The results of the discussion show that the teacher as a guide in implementing rules and procedures acts as a person with authority to manage the class and teach students to be responsible. Students who violate rules receive logical consequences while students who violate procedures will be advised and motivated. Based on the results of the analysis and discussion, before the implementation of rules and procedures, the student's discipline level was below 50\% but after the implementation of rules and procedures it was supported by the provision of logical consequences, advice and student discipline motivation increased by more than 50\%. Thus it can be concluded that the application of rules and procedures can improve student discipline. The suggestion in the future is that the application of rules and procedures will be better explained face-to-face (synchronously) during online learning so that students can more easily understand the explanation from the teacher.
\end{abstract}

Keywords: students; discipline; rules and procedures

\begin{abstract}
ABSTRAK
Kedisiplinan sangat diperlukan dalam proses pembelajaran, namun kenyataannya masih banyak siswa yang menunjukkan sikap tidak disiplin. Berdasarkan hasil observasi di beberapa kelas di salah satu Sekolah Menengah Pertama Kristen di Medan, di dapati bahawa masih terdapat siswa yang tidak mengumpulkan tugasnya lebih banyak disbanding yang mengumpulkan. Oleh karena itu, diperlukan pernerapan rules and procedures. Tujuan dari karya tulis ini untuk memaparkan tentang penerapan rules and procedures untuk meningkatkan kedisiplinan siswa. Metode penelitian yang digunakan adalah deskriptif kualitatif. Hasil pembahasan menunjukkan bahwa guru sebagai penuntun dalam penerapan rules and procedures berperan sebagai pribadi yang berotoritas untuk mengelola kelas serta mengajarkan siswa bertanggung jawab. Siswa yang melanggar rules menerima konsekuensi logis sedangkan siswa yang melanggar procedures akan dinasihati dan dimotivasi. Berdasarkan hasil analisis dan pembahasan, sebelum penerapan rule and prosedur tingkat kedisiplinan siswa di bawah $50 \%$ tetapi sesudah penerapan rules and procedures didukung pemberian konsekuensi logis, nasihat dan motivasi kedisiplinan siswa meningkat di atas $50 \%$. Dengan demikian dapat disimpulkan bahwa penerapan rules and procedures dapat meningkatkan kedisiplinan siswa. Adapun saran kedepannya adalah penerapan rules and procedures akan lebih baik dijelaskan secara tatap muka (synchronous) saat pembelajaran online agar siswa lebih mudah memahami penjelasan dari guru.
\end{abstract}

Kata Kunci: siswa; disiplin; rules and procedures

Submitted May 15, 2021 | Revised Jun 09, 2021 | Accepted Jun 18, 2021

\section{Pendahuluan}

Perilaku disiplin berkaitan erat dengan karakter siswa. Jika di dalam diri siswa sudah tertanam karakter yang disiplin, jujur, bertanggung jawab dan peduli maka bangsa Indonesia akan jauh dari perbuatan kejahatan, korupsi dan tindakan amoral lainnya sehingga menghasilkan penerus bangsa yang maju, damai dan sejahtera (Hanifah \& Julia, 2014). Oleh karena itu, dengan memiliki karakter yang disiplin maka siswa akan memiliki kehidupan yang berdampak positif bagi bangsa Indonesia.

Menurut Gunawan (2019) disiplin adalah suatu perilaku yang menghormati, menghargai dan patuh terhadap peraturan yang berlaku di lingkungannya. Tu'u dalam Septiani (2017) menambahkan 
bahwa disiplin itu penting karena dapat menyadarkan siswa untuk tidak menyimpang dari peraturan sekolah, proses pembelajaran di sekolah berjalan dengan kondusif dan siswa menjadi pribadi yang teratur. Disiplin mendorong diri siswa untuk menjalankan peraturan sekolah dan ketika melanggar peraturan maka siswa menerima dampak dari perbuatannya. Selain itu, disiplin juga memiliki tujuan dalam kehidupan siswa. Tujuan dari disiplin bukan hanya sekedar untuk menaati peraturan saja tetapi membentuk siswa menjadi pribadi yang memiliki tanggung jawab kepada diri sendiri dan orang lain (Suradi, 2017). Oleh sebab itu, siswa diharapkan untuk dapat disiplin.

Namun pada kenyataannya, masih banyak siswa yang menunjukkan perilaku tidak disiplin saat pembelajaran online sedang berlangsung pada masa pandemi virus corona. Pelanggaran dalam hal ini disebut dengan tindakan ketidakdisiplinan siswa. Sebagaimana menurut Susanto (2018) bahwa tindakan tidak disiplin siswa adalah pelanggaran yang dilakukan terhadap peraturan yang telah ditetapkan oleh guru di kelas. Melalui pernyataan tersebut, penulis menemukan tindakan pelanggaran yang dilakukan oleh siswa dalam hal pengumpulan tugas. Berdasarkan data hasil refleksi observasi, ketidakdisiplinan yang dilakukan siswa pada beberapa kelas adalah jumlah siswa yang tidak mengumpulkan tugas lebih banyak dari pada yang mengumpulkan tugas. Sama halnya dengan data hasil refleksi mengajar yang dilakukan oleh penulis bahwa pelanggaran yang dilakukan siswa adalah terdapat siswa yang tidak memberikan tugasnya tepat waktu.

Adapun penyebab siswa melakukan pelanggaran dipengaruhi faktor internal dan eksternal. Faktor internal adalah faktor yang berasal dari dalam diri siswa seperti malas, tidak memiliki minat serta kurangnya kesadaran siswa untuk menaati aturan sedangkan faktor eksternal adalah faktor yang berasal dari luar diri siswa seperti kondisi keluarga, masyarakat maupun penerapan pendisiplinan dari guru di sekolah (Sugiarto, Suyanti, \& Yulianti). Oleh sebab itu perilaku yang ditunjukkan oleh siswa dapat dipengaruhi oleh suatu kondisi sehingga pada akhirnya siswa tidak disiplin.

Berdasarkan tindakan ketidakdisiplinan yang terjadi, dasar dari permasalahnya adalah pribadi siswa yang kurang memiliki rasa tangggung jawab terhadap peraturan yang di tetapkan di sekolah. Menurut Rochmah (2016) perilaku tidak bertanggung jawab pada siswa seperti perilaku malas, menundanunda pekerjaan, mencari-cari alasan ketika pekerjaannya tidak dikerjakan atau tidak mengumpulkan tugasnya. Wardhani (2018) juga menambahkan bahwa terdapat dua hambatan yang dialami siswa sehingga melakukan tindakan ketidakdisiplinan yaitu: 1) Siswa tidak memahami peraturan yang telah diberikan oleh guru; 2) Siswa mengetahui peraturan tetapi berpura-pura tidak mengetahuinya.

Masalah ketidakdisiplinan siswa dapat berdampak tidak baik bagi diri siswa maupun lingkungan sekolah. Ningsih (2014) menyatakan bahwa pengaruh yang terjadi jika siswa tidak disiplin di sekolah adalah prestasi siswa dapat menurun dan kegiatan pembelajaran tidak dapat berjalan dengan baik. Lickona dalam Rachman \& Agustian (2016) juga mengatakan bahwa Tindakan ketidakdisiplinan siswa merupakan kendala dalam hal moralitas yang semakin serius dan meningkat dari tahun ke tahun. Jika hal tersebut dibiarkan maka perilaku buruk siswa akan merajalela sehingga dapat merugikan diri sendiri dan orang lain.

Oleh sebab itu, untuk mengatasi masalah ketidakdisiplinan siswa maka dibutuhkan kerja keras guru agar dapat mendorong siswa disiplin. Salah satunya adalah dengan menerapkan rules and procedures di dalam kelas. Saemara, Zendrato, \& Roselyna (2016) mengatakan bahwa kedisiplinan siswa dapat meningkat melalui pemberian rules and procedures di dalam kelas. Rachman \& Agustian (2016) juga mengatakan rules and procedures harus dijalankan di dalam kelas sehingga meningkatkan kedisiplinan siswa untuk mengikuti setiap pembelajaran di sekolah. Nasriyah, Israwati, \& Elly (2017) menambahkan bahwa rules and procedures yang tetap dapat meningkatkan kedisiplinan siswa karena membiasakan siswa untuk hidup teratur. Berdasarkan pendapat para ahli tersebut, dapat disimpulkan bahwa penerapan rules and procedures dapat meningkatkan kedisiplinan siswa. 
Dengan demikian yang menjadi rumusan masalah adalah bagaimana penerapan rules and procedures agar dapat meningkatkan kedisiplinan siswa? Kemudian yang menjadi tujuan penelitian ini adalah memaparkan tentang penerapan rules and procedures agar dapat meningkatkan kedisiplinan siswa. Adapun manfaat penelitian ini secara praktis bagi siswa adalah agar dapat disiplin dalam mengerjakan tugas yang diberikan guru. Selain itu manfaat penelitian bagi guru adalah agar dapat memanajemen kelas dengan baik sedangkan manfaat penelitian bagi sekolah yaitu mendorong kegiatan pembelajaran dapat berjalan dengan baik.

\section{Metode Penelitian}

Metode penelitian yang digunakan adalah metode kualitatif deskriptif. Metode kualitatif deskriptif adalah pengumpulan data verbal yang didasari oleh fenomena alamiah yang dialami oleh penulis dengan cara mendeskripsikan fakta yang terjadi di lapangan (Creswell \& Meleong dalam Sugiarti \& Andalas, 2020). Ismail \& Hartanti (2019) juga menyatakan bahwa penelitian kualitatif deskriptif berangkat dari data lapangan yang telah dilakukan kemudian didukung dengan teori-teori yang sudah ada. Adapun prosedur yang digunakan dalam penelitian ini ada empat. Sebagaimana (Mustafa, 2020) menyatakan bahwa prosedur penelitian kualitatif deskriptif adalah: 1) Tahap pra-lapangan yakni pemilihan lapangan penelitian; 2) Tahap kegiatan lapangan yaitu peneliti melakukan praktek lapangan dan mengumpulkan data; 3) Tahap analisis data yaitu data yang diperoleh diorganisasikan, dipilah-pilah dan menemukan sesuatu yang penting untuk dipelajari; 4) Penulisan laporan akhir yakni hasil data yang disusun dijadikan sebagai hasil dari laporan penelitian yang dapat diceritakan kepada orang lain.

Sumber data yang digunakan penulis yaitu sumber data primer dan data sekunder. Sumber data primer adalah hasil observasi langsung yang dilakukan penulis dan instrumen data sekundernya adalah hasil refleksi observasi, refleksi mengajar, penilaian guru mentor dan RPP. Tempat penelitian yang dilakukan penulis adalah pada salah satu Sekolah Menengah Pertama Kristen di Medan. Waktu penelitian adalah dari Senin, 3 Agustus 2020 hingga Senin, 24 Agustus 2020. Subjek penelitian ini adalah 97 orang dimana jumlah siswa kelas $7 \mathrm{~A}$ adalah 32 orang, siswa kelas $7 \mathrm{~B}$ sebanyak 32 orang, siswa kelas 8 A adalah 32 orang, siswa kelas $9 \mathrm{~B}$ sebanyak 32 orang dan 1 guru mentor.

Instrumen penelitian adalah peneliti sendiri dengan mengumpulkan data menggunakan teknik observasi dan dokumentasi. Hasanah (2017) mengatakan bahwa teknik observasi adalah pengamatan yang dilakukan saat kegiatan sedang berlangsung menggunakan panca indera sedangkan teknik dokumentasi adalah pengumpulan data berupa catatan harian, foto, hasil rapat dan sebagainya. Adapun teknik analisis data yang digunakan peneliti yaitu teknik analisis interaktif. Subandi (2011) mengatakan bahwa teknik analisis data interaktif terbagi atas tiga bagian yaitu: 1) Reduksi data dimana peneliti mengatur data sehingga memperoleh pokok temuan yang akan dibahas; 2) Penyajian data yakni peneliti menyusun data dengan baik sehingga memiliki gambaran data secara keseluruhan agar dapat dipahami dengan baik; 3) Penarikan kesimpulan yaitu peneliti telah menyeleksi data dari proses awal data diperoleh sehingga dapat menarik suatu kesimpulan.

\section{Hasil dan Pembahasan}

Kedisiplinan dari siswa menjadi salah satu kunci berhasilnya suatu proses pembelajaran. Kedisiplinan merupakan bagian dari pendidikan karakter yang berhubungan dengan keteraturan dalam diri siswa sehingga berdampak kepada berhasilnya suatu aktivitas pembelajaran disekolah (Rachman \& Agustian, 2016). Fiara, Nurhasanah, \& Bustamam (2019) juga menambahkan bahwa melalui kedisiplinan siswa dapat menyelesaikan tingkat pendidikan yang sedang dijalani dan berpengaruh kepada langkah sukses siswa dalam menggapai cita-cita yang mereka inginkan. Melalui kedisiplinan siswa akan terdorong untuk mampu merancangkan masa depan mereka. 
Siswa yang disiplin juga mampu beradaptasi di lingkungan sekolah. Sebagaimana pendapat dari (Sobri, 2019) bahwa kedisiplinan dalam diri siswa dapat membantu mereka untuk beradaptasi terhadap lingkungan karena siswa dapat belajar membiasakan diri kepada hal yang berguna baik terhadap diri mereka maupun kepada orang lain. Sikap disiplin membuat siswa dapat diterima karena dapat memenuhi standar yang berlaku dalam suatu lingkungan tersebut.

Meskipun kedisiplinan merupakan hal yang penting, tetapi masih terdapat siswa yang melakukan pelanggaran sehingga memberikan dampak negatif. Penyebab siswa melakukan tindakan yang tidak disiplin melalui dua faktor yaitu faktor internal dan eksternal. Faktor internal adalah faktor yang berasal dari dalam diri siswa seperti malas, lupa, tidak berminat dan tidak terbiasa disiplin. Kemudian faktor eksternal adalah faktor yang berasal dari luar diri siswa seperti kondisi keluarga, pengaruh pertemanan maupun cara pengajaran guru (Putri, 2018). Berdasarkan data refleksi mengajar, siswa memberikan beberapa alasan yang menjadi faktor mengapa mereka melakukan tindakan yang tidak disiplin selama pembelajaran online. Faktor internalnya seperti lupa memberikan tugas dan menganggap diri tidak berbakat sehingga tidak mengikuti instruksi yang telah diberikan. Kemudian faktor eksternalnya terdapat siswa tidak memberikan tugasnya karena kondisi orangtuanya yang sedang sakit. Berdasarkan beberapa faktor tersebut siswa akhirnya melakukan tindakan yang tidak disiplin.

Adapun bentuk ketidakdisiplinan yang dilakukan siswa berdasarkan data hasil refleksi observasi adalah pada beberapa kelas, jumlah siswa yang tidak mengumpulkan tugas lebih banyak dari pada yang mengumpulkan tugas kepada guru. Sama halnya dengan data hasil refleksi mengajar yang dilakukan oleh penulis bahwa pelanggaran yang dilakukan siswa adalah tidak memberikan tugasnya tepat waktu. Masalah yang ditemukan tersebut sesuai dengan teori indikator ketidakdisiplinan. Syafrudin dalam Ria \& Rosdiana (2014) mengatakan bahwa indikator ketidaktaatan siswa ketika mengikuti pembelajaran yakni ketidaktaatan siswa terhadap waktu belajar, siswa tidak taat untuk memberikan tugasnya kepada guru dan ketidaktaatan siswa dalam penggunaan fasilitas dalam proses pembelajaran. Berdasarkan indikator tersebut masalah yang ditemukan yaitu siswa tidak mengumpulkan tugasnya sesuai dengan instruksi yang diberikan.

Masalah ketidakdisiplinan siswa dapat diatasi oleh guru yang bertugas untuk menuntun siswa menjadi pribadi yang bertanggung jawab. Guru sebagai penuntun dapat menerapkan rules and procedure yang dapat memberikan dampak positif bagi siswa. Tanfidiyah (2017) menyatakan bahwa peraturan tertulis biasanya menggunakan rules and procedures sebagai peraturan kelas agar dapat mendisiplinkan siswa. Meskipun demikian, rules and procedures merupakan hal berbeda. Ruyatnasih \& Megawati (2018) mengatakan bahwa rules adalah tindakan yang dilakukan secara khusus dalam suatu keadaan tertentu sedangkan procedures adalah cara dalam bertindak melalui urutan atau petunjuk bagaimana seseorang harus melaksanakan pekerjaannya yang di implementasikan pada waktu yang akan datang. Widiasworo (2018) juga menambahkan bahwa dalam konteks peraturan di kelas rules adalah pernyataan tentang halhal yang dapat atau yang tidak dapat dilakukan siswa (peraturan) dan procedures merupakan cara atau petunjuk yang dilakukan siswa sebagai pembiasaan untuk memanajemen kelas dengan baik seperti cara izin ke toilet, cara bekerja sama dengan siswa atau cara agar siswa tidak ribut. Oleh sebab itu procedures merupakan petunjuk yang digunakan untuk mendukung tercapainya rules yang diberikan guru.

Rules and procedures memberikan dampak positif baik bagi siswa maupun lingkungan sekolah. Pelawi, Zendrato, \& Roselyna (2016) mengatakan bahwa fungsi rules and procedures adalah membuat proses pembelajaran berlangsung dengan baik, kedisiplinan siswa dapat meningkat, siswa dapat memahami mengapa rules and procedures diberikan sehingga berusaha mematuhinya. Adapun tujuan rules and procedures adalah menanamkan kedisiplinan kepada siswa sebagai pembentukan moralitas individu yang akan membentuk kebiasaan siswa untuk bertanggung jawab (Fawaid, 2017). Oleh sebab itu, rules and procedures akan membuat siswa terbiasa taat terhadap arahan dari guru. 
Rules and procedures efektif untuk diterapkan kepada siswa. Hasil penelitian yang relevan dari (Rahman, 2016) menyatakan rules and procedures dapat meningkatkan kedisiplinan siswa dalam mengikuti setiap kegiatan selama proses pembelajaran sehingga guru efektif untuk mengelola kelas. Selain itu, rules and procedures menunjukkan peningkatan persentase kedisiplinan siswa yang signifikan. Sebagaimana hasil penelitian dari (Kurniasih, 2018) menyatakan bahwa kedisiplinan siswa dapat meningkat melalui penerapan rules and procedure di dalam kelas dari yang sebelumnya 16,63\% menjadi diatas $90 \%$.

Adapun implementasi rules and procedures diterapkan oleh penulis sehingga dapat meningkatkan kedisiplinan siswa dalam mengumpulkan tugasnya saat pembelajaran online. Berdasarkan data refleksi mengajar, penulis memberikan rules and procedures yang berkaitan dengan pengumpulan tugas di kelas. Rules yang diberikan adalah siswa memberikan tugas tepat waktu. Procedures yang harus dilaksanakan adalah pengumpulan tugas diberikan melalui google classroom dan jika google classroom siswa bermasalah dapat mengirimkan tugas melalui telegram penulis.

Penerapan rules and procedure yang diterapkan peneliti sudah sesuai. Sebagaimana Weinstein dalam Wahid, Muali, \& Mutmainnah (2017) mengatakan bahwa penerapan rules and procedures yang diterapkan di kelas ketika mengajar memiliki prinsip yaitu: 1) rules and procedures diberikan secara wajar berdasarkan keperluan siswa agar proses pembelajaran kondusif; 2) rules yang diberikan harus jelas dan procedures yang berisi petunjuk-petunjuknya mudah dipahami siswa; 3) rules and procedures yang ditetapkan agar tujuan pembelajaran tercapai; 4) memberikan evaluasi apakah siswa mengikuti rules maupun procedures atau tidak. Berdasarkan hasil refleksi mengajar bahwa hasil presentase kedisiplinan siswa yang diperoleh penulis ketika observasi (sebelum penerapan rules and procedures) dan sesudah penerapan rules and procedures.

Tabel 1. Presentase Pengumpulan Tugas Siswa Ketika Observasi

\begin{tabular}{ccc}
\hline Kelas & $\begin{array}{c}\text { Tidak } \\
\text { Mengumpulkan }\end{array}$ & Mengumpulkan \\
\hline 7 A & $43,750 \%$ & $56,250 \%$ \\
8 A & $56,250 \%$ & $43,750 \%$ \\
9 B & $65,625 \%$ & $34,275 \%$ \\
\hline
\end{tabular}

Tabel 2. Presentase Pengumpulan Tugas Siswa Setelah Penerapan Rules and Procedures

\begin{tabular}{ccc}
\hline Kelas & $\begin{array}{c}\text { Tidak } \\
\text { Mengumpulkan }\end{array}$ & Mengumpulkan \\
\hline 7 A & $12,500 \%$ & $87,500 \%$ \\
7 B & $6,250 \%$ & $93,750 \%$ \\
8 A & $21,875 \%$ & $84,375 \%$ \\
\hline
\end{tabular}

Berdasarkan tabel 1 dan 2, presentase kedisiplinan siswa dalam mengumpulkan tugas lebih tinggi ketika rules and procedures sudah diterapkan daripada kedisiplinan siswa ketika observasi. Meskipun demikian masih terdapat siswa yang melakukan pelanggaran terhadap rules and procedures yang diberikan. Berdasarkan refleksi mengajar beberapa siswa melanggar rules dengan tidak memberikan tugasnya tepat waktu (menyerahkan tugasnya sangat lama hingga dalam jangka satu minggu). Berdasarkan hal tersebut maka diberikan konsekuensi logis.

Konsekuensi logis membuat siswa berwewenang dalam memilih suatu keputusan dan siap bertanggung jawab menerima dampak dari perbuatannya karena konsekuensi logis yang diberikan sudah berdasarkan kesepakatan. Konsekuensi logis merupakan hasil atau akibat dari keputusan yang dipilih oleh siswa baik berupa hasil yang baik atau yang tidak baik (Smith, 2019). Bukhari (2015) juga menambahkan bahwa konsekuensi logis adalah tindak lanjut yang diberikan jika anak melanggar peraturan yang telah ditetapkan dan konsekuensi logis harus diberikan berdasarkan kesepakatan. 
Melalui hasil refleksi mengajar penulis memberikan konsekuensi logis berdasarkan dua pilihan yang hasilnya dapat berdampak baik dan buruk. Kemudian konsekuensi logis tersebut juga diberikan berdasarkan hasil kesepakatan antara siswa, mentor (guru pembimbing) dan penulis. Konsekuensi logis yang diberlakukan ketika mengajar adalah siswa diberikan waktu pengerjaan tugas selama dua hari dan jika memberikan tugas tepat waktu maka akan memperoleh nilai $(+10)$ dan jika terlambat akan memperoleh nilai $(-10)$. Oleh sebab itu hasil yang diterima ketika diberikan konsekuensi logis adalah sebagai berikut.

Tabel 3. Presentase Pengumpulan Tugas Siswa Setelah Pemberian Konsekuensi Logis

\begin{tabular}{ccc}
\hline Kelas & $\begin{array}{c}\text { Tidak } \\
\text { Mengumpulkan }\end{array}$ & Mengumpulkan \\
\hline 7 A & $15,625 \%$ & $84,375 \%$ \\
7 B & $6,250 \%$ & $93,750 \%$ \\
8 A & $21,875 \%$ & $78,125 \%$ \\
\hline
\end{tabular}

Berdasarkan tabel 3, persentase kedisiplinan siswa dalam pengumpulan tugas masih tinggi. Hal yang membedakannya adalah siswa yang mengumpulkan tugas tepat waktu sudah lebih banyak agar memperoleh poin (+10). Berdasarkan dua pilihan konsekuensi logis, siswa lebih memilih yang hasilnya dapat berdampak baik.

Adapun siswa yang melanggar procedures maka diberikan motivasi dan nasihat. Motivasi dan nasihat sering diberikan secara bersamaan namun kedua hal tersebut berbeda. Motivasi adalah sesuatu hal yang diberikan sebagai penggerak agar siswa dapat terpengaruh untuk melakukan suatu tujuan. Motivasi berasal dari bahasa latin yaitu "movare" yang artinya to move (menggerakkan) sehingga motivasi adalah sesuatu yang dapat menggerakkan dan mempengaruhi agar dapat melakukan suatu hal serta mendorong seseorang bangkit dari keterpurukan untuk memperbaiki kesalahan yang dilakukan (Duha, 2020). Melalui pemberian motivasi siswa yang tidak disiplin akan merasa bahwa dirinya masih berguna sehingga akan berusaha untuk bangkit dan memperbaiki kasalahannya.

Nasihat diberikan melalui kalimat yang menyentuh hati dan lembut sehingga siswa menyadari kesalahan yang diperbuat siswa sebelumnya. Nasihat berasal dari kata "nash" artinya murni dan tidak menggunakan kata-kata kotor sehingga nasihat adalah kalimat yang menggunakan kata-kata lembut dan tidak menyakiti perasaan orang tersebut sehingga dapat membangun kesadaran diri untuk melakukan perbuatan baik (Rosikum, 2018). Ketika diberikan nasihat kepada siswa yang tidak disiplin melalui kata-kata yang menyentuh hati maka siswa akan menyadari bahwa dirinya diperhatikan sehingga siswa akan melakukan perbuatan yang lebih baik dari sebelumnya.

Berdasarkan data refleksi mengajar pemberian nasihat dan motivasi lebih banyak diberikan pada penerapan procedures. Sedangkan pada penerapan konsekuensi logis nasihat dan motivasi lebih sedikit karena siswa yang memberikan tugas tepat waktu sudah lebih banyak. Oleh sebab, hasil penelitian yang diperoleh adalah kedisiplinan siswa meningkat dalam hal pengerjaan tugas ketika rules and procedure diterapkan. Sebelum penerapan rules and procedures kedisiplinan siswa masih terdapat dibawah $50 \%$ dalam satu kelas tetapi setelah diterapkan rules and procedures tingkat kedisiplinan siswa diatas $50 \%$. Ketika siswa melanggar rules and procedures maka dapat diberikan konsekuensi logis, nasihat dan motivasi. Melalui penerapan tersebut siswa dapat taat berdasarkan kehendak hati mereka sendiri.

\section{Kesimpulan}

Penerapan rules and procedures diterapkan oleh guru sebagai penuntun karena berperan sebagai pemegang otoritas agar dapat mengatur, mengelola maupun mengoreksi perilaku siswa. Rules and procedures yang diterapkan guru menunjukkan bagaimana siswa dapat mengendalikan diri dan bertanggung jawab terhadap perilaku mereka berdasarkan kehendak sendiri. Melalui penerapan rules and procedures 
kedisiplinan siswa dapat meningkat. Hal ini diketahui berdasarkan pemberian rules and procedures dalam hal pengumpulan tugas. Ketika siswa melanggar rules pengumpulan tugas yang diberikan maka diberlakukan konsekuensi logis berdasarkan hasil kesepakatan bersama. Kemudian ketika siswa melanggar procedures yang telah diberikan maka siswa diberikan nasihat dan motivasi agar siswa dapat memperbaiki perilaku tidak disiplin mereka. Hasil yang diperoleh menunjukkan peningkatan dimana ketika observasi di awal kedisiplinan siswa masih dibawah 50\% tetapi sesudah penerapan rules and procedures yang didukung oleh pemberian konsekuensi logis, nasihat dan motivasi kedisiplinan siswa meningkat diatas $50 \%$. Adapun saran untuk kedepannya adalah penerapan rules and procedures dalam mendisiplinkan siswa akan lebih baik jika dijelaskan dengan cara tatap muka secara langsung melalui aplikasi seperti google meet atau teams (synchronous) saat pembelajaran online. Melalui penjelasan secara tatap muka maka siswa akan lebih memahami rules and procedures yang diberikan guru dengan jelas karena jika melalui chatting (asynchronous) maka siswa akan sering mempertanyakan rules and procedures yang telah diberikan. Hal ini menyebabkan guru harus sabar menjelaskannya berulangkali melalui chat agar siswa dapat memahami rules and procedures yang diberikan dengan baik.

\section{Daftar Pustaka}

Bukhari, I. B. (2015). Dari Abah Ibsan: 7 Kiat Orangtua Shalih Menjadikan Anak Disiplin dan Bahagia. Mizani.

Duha, T. (2020). Motivasi untuk Kinerja. CV Budi Utama.

Fawaid, M. M. (2017). Implementasi Tata Tertib Sekolah Dalam Meningkatkan Karakter Kedisiplinan Siswa. Jurnal Civic Hukum, 9-19. doi:http://ejournal.umm.ac.id/index.php/jurnalcivichukum/article/view/9899

Fiara, A., Nurhasanah, \& Bustaman, N. (2019). Analisis Faktor Penyebab Perilaku Tidak Dsisiplin Pada Siswa SMP Negeri 3 Banda Aceh. Jurnal Ilmiah Mahasiswa Bimbingan Dan Konseling, 1-6. doi:http://jim.unsyiah.ac.id/pbk/article/view/6211/0

Gunawan, I. (2019). Manajemen Kelas: Teori dan Aplikasinya. Rajawali Pers.

Hasanah, H. (2017). Teknik-Teknik Observasi. Walisongo, 21-46. doi:https://journal.walisongo.ac.id/index.php/attaqaddum/article/view/1163

Kurniawan, Y. (2019). Inovasi Pembelajaran Model dan Metode Pembelajaran Bagi guru. Kekata.

Mustafa, P. S. (2020). Metodologi Penelitian Kuantitatif, Kualitatif, dan Penelitian Tindakan Kelas dalam Pendidikan Olahraga. Fakultas Ilmu Keolahragaan Universitas Negeri Malang.

Nasriyah, S. A., Israwati, \& Elly, R. (2017). Penerapan Disiplin Dalam Proses Pembelajaran Pada Tingkat Kelas Tinggi Di SD Negeri 22 Banda Aceh. Jurnal Ilmiah Pendidikan Guru Sekolah Dasar, 48-57. doi:http://jim.unsyiah.ac.id/pgsd/article/view/7018

Ningsih, B. M. (2014). Peningkatan Disiplin Siswa dengan Layanan Informasi Media Film. Jurnal Bimbingan Dan Konseling, 73-92. doi:http://journal.upgris.ac.id/index.php/EMPATI/article/view/660

Pelawi, E. S., Zendrato, J., \& Sitompul, L. R. (2016). Penetapan dan Penerapan Peraturan Spesifik untuk Meningkatkan Kedisiplinan Siswa Kelas VIII. A Journal of Language, Literature, Culture, and Education, 60-69. A Journal of Language, Literature, Culture, and Education

Putri, N. R. (2018). Analisis Tindak Indisipliner Siswa SMP Negeri. JSMP, 122-128. doi:http://journal2.um.ac.id/index.php/jmsp/article/view/2637

Rachman, A., \& Agustian, M. (2016). Meningkatkan Kedisiplinan Siswa Melalui Pengelolaan Kelas di SDN 23 Pagi Palmerah Jakarta. Jurnal Perkotaan, 75-93. doi:http://ejournal.atmajaya.ac.id/index.php/perkotaan/article/view/277

Rahman, S. H. (2016). Implementasi Peraturan Sekolah dalam Meningkatkan Kedisiplinan Guru dan Siswa. Universitas Islam Maulana Malik Ibrahim Malang. 
Ria, E., \& R. (2014). Pengaruh Disiplin Belajar Dan Perhatian Orang Tua Terhadap Hasil Belajar Matematika Siswa Kelas X SMA Negeri 1 Kusambi. Jurnal Penelitian Pendidikan Matematika, 28-42. doi:http://ojs.uho.ac.id/index.php/JPPM/article/view/3074

Rochman, E. Y. (2016). Mengembangkan Karakter Tanggung Jawab Pada Pembelajar. Al Murabbi. doi:http://ejournal.kopertais4.or.id/mataraman/index.php/murabbi/article/download/1700/12 $56 /$

Ruyatnasih, Y., \& Megawati, L. (2018). Manajemen Teori, Fungsi dan Kasus. CV.Absolute Media.

Saemara, E. P., Zendrato, J., \& Roselyna, L. S. (2016). Penetapan dan Penerapan Peraturan Spesifik untuk Meningkatkan Kedisiplinan Siswa Kelas VIII SMP ABC Cikarang. Polyglot, 60-69. doi:https://ojs.uph.edu/index.php/PJI/article/view/365

Septiani. (2017). Pengaruh Pemberian Beasiswa Bidik Misi Terhadap Motivasi Berprestasi Dan Disiplin Mahasiswa. Jumal Ilmiah Ekonomi Global Masa Kini, 6-11. http://ejournal.uigm.ac.id/index.php/EGMK/article/view/325

Smith, S. O. (2019). Gentle Discipline. Bentang.

Sobri, M. (n.d.). Pembentukan karakter disiplin siswa melalui kultur sekolah. Jurnal Pendidikan IPS, 6171. doi:https://journal.uny.ac.id/index.php/hsipi/article/view/26912

Subandi. (2011). Deksripsi Kualitatif Sebagai Satu Metode Dalam Penelitian Pertunjukan. Harmonia, 173179. doi:https://journal.unnes.ac.id/nju/index.php/harmonia/article/view/2210

Sugiarti, \& Andalas, E. F. (2020). Desain Penelitian Kualitatif Sastra. UMM Press.

Sugiarto, A. F., Suyanti, T., \& Yulianti, P. D. (2019). Faktor Kedisiplinan Belajar Pada Siswa Kelas X SMK Larenda Brebes. Jurnal Mimbar Ilmu, 232-238. https://ejournal.undiksha.ac.id/index.php/MI/article/view/21279

Suradi. (2017). Pembentukan Karakter Siswa melalui Penerapan Disiplin Tata Tertib Sekolah. Jurnal Riset Dan Konseptual, 522-533. doi:https://www.researchgate.net/publication/321041635_Pembentukan_Karakter_Siswa_melal ui_Penerapan_Disiplin_Tata_Tertib_Sekolah

Susanto, A. (2018). Bimbingan dan Konseling di Sekolah. Kencana.

Tanfidiyah, N. (2017). Pengembangan Peraturan Kelas sebagai Upaya Kuratif Terhadap Perilaku Menyimpang Siswa dalam Pembelajaran Tematik Terpadu di Kelas IV MIN Yogyakarta I. Pionir Jurnal Pendidikan, 126-145. doi:https://jurnal.ar-raniry.ac.id/index.php/Pionir/article/view/4591

Wahid, A. H., Muali, C., \& M. (2017). Manajemen Kelas dalam Menciptakan Suasana Belajar yang Kondusif; Upaya Peningkatan Prestasi Belajar Siswa. Jurnal Al-Fikrah, 180-193. https://docplayer.info/94790271-Manajemen-kelas-dalam-menciptakan-suasana-belajar-yangkondusif-upaya-peningkatan-prestasi-belajar-siswa.html

Wardhani, M. W. (2018). Faktor-faktor Penyebab Rendahnya Kedisiplinan Siswa SDN Kepek Pengasih Kulon Progo Yogyakarta. Jurnal Pendidikan Guru Sekolah Dasar, 1.877-1.886. doi:http://journal.student.uny.ac.id/ojs/index.php/pgsd/article/view/11611

Widiasworo, E. (2018). Cerdas Pengelolaan kelas. Diva Press. 